RASĀYAN J. Chem.

Vol. 13 | No. 3 |1372-1378| July - September | 2020 ISSN: 0974-1496 | e-ISSN: 0976-0083 | CODEN: RJCABP

\title{
PRODUCTION OF CHELATE POLYMER-CONTAINING MICROFERTILIZERS BASED ON HUMIC ACID AND AMMOPHOS
}

\author{
Smailov B. M. ${ }^{1, *}$, Beisenbayev Oral Kurganbekovich ${ }^{1}$, Tleuov Alibek \\ Spabekovich ${ }^{1}$, Kadirbaeva Almagul Akkopeykyzy ${ }^{1}$, Zakirov Bakhtiyar $^{1}$ \\ Sabirjanovich $^{2}$ and Mirzoyev Bahodur ${ }^{3}$ \\ ${ }^{1}$ M. Auezov South Kazakhstan State University/ Department of Chemical Technologies of \\ Inorganic Substances, 160012, Shymkent, Kazakhstan \\ ${ }^{2}$ Institute of General and Inorganic Chemistry, Tashkent, 100047, The Republic of Uzbekistan \\ ${ }^{3}$ Department of Chemical Technologies of Inorganic Substances / Branch of M.V. Lomonosov \\ Moscow State University in Dushanbe, 734003, \\ Dushanbe, Republic of Tajikistan \\ E-mail: Baha_uppr@mail.ru
}

\begin{abstract}
ABSTARCT
The present article considers the production process of chelate polymer-containing micro fertilizers based on the humic acid obtained at the decomposition of a coal waste of the Lenger deposit (Kazakhstan) and etherified derivatives of hydrolyzed polyacrylonitrile (EDPAN). The chemical composition of the initial components and produced polymer-containing micro fertilizer determined using scanning electron microscopy, differential thermal and infrared analysis is given. To improve the quality of the fertilizer produced, boric acid, copper sulphate, iron sulphate and ammonium molybdate were added as microelements and the EDPAN as a chelation agent. In the course of the research, it was found that EDPAN acts as a chelation agent owing to the content of carboxyl groups of fatty acids and increases the assimilability of microelements by plants. Also, the elemental analysis showed that the introduction of EDPAN into the mixture promotes the formation of a granular crystalline structure of the chelate polymer-containing micro fertilizers. The micro fertilizers produced are characterized by a high content of humic substances, which participate in the soil structurization, accumulation of macro and micronutrients in the assimilable form and are intended for raising the level of crop yield.
\end{abstract}

Keywords: Polymer-containing Micro Fertilizer, Coal, Humic Acid, Ammophos, Microelement, Chelation AgentEDPAN.

(C) RASĀYAN. All rights reserved

\section{INTRODUCTION}

One of the most important problems of the agricultural branch is the increase in soil fertility that directly influences on increase in the productivity of crops. Today, the search for new nontoxic and high effective mineral fertilizers and chelate micro fertilizers is extremely urgent. These fertilizers can be successfully applied at the cultivation of agricultural raw materials, and also for solving a narrower, but the very pressing problem - production of materials with raised content of essential microelements.

There is the way according to which the fertilizers can be produced at simultaneous processing of alkaline metals' humates and salts of microelements in a solid phase with the subsequent mechano-chemical activation of the mixture obtained in the presence of an oxidizer (potassium permanganate) and an alkaline agent (potash). This way allows us to produce the chelate complexes of humic acids enriched with microelements. ${ }^{1}$ The disadvantages of this method are incomplete solubility of the product in water and complex and expensive technological equipment.

The purpose of the present research was the development of the production method of a polymercontaining micro fertilizer providing a decrease in the cost price of the process, improvement of quality of the ready product and partial solution of the problem of recycling technogenic wastes.

Rasayan J. Chem., 13(3), 1372-1378(2020)

http://dx.doi.org/10.31788/RJC.2020.1335726 
RASĀYAN J. Chem.

Vol. 13 | No. 3 |1372-1378| July - September | 2020

The assigned task can be solved if to produce chelate polymer-containing micro fertilizers based on the humic acid, obtained at the decomposition of the Lenger brown coal waste, ammophos and $0,5 \%$ of EDPAN. To increase the phosphorus content in the fertilizer and enrich the product with microelements, the mixture obtained is mixed with ammophos, $0,5 \%$ of boric acid, $0,5 \%$ of copper sulphate, $1,5 \%$ of potassium sulphate and $1,5 \%$ of ammonium molybdate.

The suggested way allows us to produce the polymer-containing micro fertilizer based on brown coal of the Lenger deposit with the addition of EDPAN as a chelation agent that contains all microelements necessary for growth and development of crops.

The manufacture of a polymer-containing micro fertilizer based on humic acid and ammophos permits us to improve the quality of the ready products, decrease in their cost price at the expense of application of the technogenic waste, and improve the environmental conditions of the region.

\section{EXPERIMENTAL}

The initial materials were the humic acid, obtained at the decomposition of the coal waste of the Lenger deposit, ammophos as a phosphorus-containing component and a chelation agent - EDPAN. The physical and chemical properties and application of these substances are represented below.

Physical and chemical properties of the initial raw materials and end polymer-containing micro fertilizers were studied using experimental physicochemical and analytical methods such as electronic microscopy, infrared spectroscopy, elemental analysis and differential thermal analysis (DTA).

Ammophos is a high-concentrated complex nitrogen-phosphorus fertilizer; the total content of nutrients reaches $64 \%$ including $12 \%$ of nitrogen and $52 \%$ of phosphorus. Phosphorus in it is in a water-soluble form and is easily assimilated by plants on all types of soils. Ammophos has good physicochemical and mechanical properties: it is nonhygroscopic, is not caked, does not dust, and has a homogeneous granulometric composition. The physical and chemical characteristics of ammophos are represented in Table-1.

Table-1: Physical and Chemical Characteristic of Ammophos

\begin{tabular}{l|c}
\hline \multicolumn{1}{c}{ Characteristic } & Parameter \\
\hline Assimilable phosphate $\left(\mathrm{P}_{2} \mathrm{O}_{5}\right)$, not less than, $\%$ & 52 \\
\hline Water-soluble phosphate $\left(\mathrm{P}_{2} \mathrm{O}_{5}\right), \%$ & $47-49$ \\
\hline Total nitrogen, not less than, $\%$ & 12 \\
\hline Hygroscopic point, $\%$ at $\mathrm{T}=25^{\circ} \mathrm{C}$ & $63-68$ \\
\hline Apparent density, $\mathrm{t} / \mathrm{m}^{3}$ & $0,80-0,90$ \\
\hline Water, not more than, $\%$ & 1 \\
\hline
\end{tabular}

Ammophos is successfully applied as a basic, presowing and, especially, row fertilizer for various crops in all soil-climatic zones of the country. At applying in neutral and alkalescent soils (carbonate chernozem, meadow-forest carbonate soils, chestnut soils, sierozem) creates a more favorable phosphatic mode in comparison with other fertilizers. The use of ammophos in a dissolved kind as a phosphoruscontaining component is of great importance at the manufacture of a polymer-containing fertilizer. ${ }^{2}$

The etherified derivatives of hydrolyzed polyacrylonitrile (EDPAN) represent a transparent oily liquid sometimes with tints of yellow. It is widely applied at fertilizer production plants as a chelation agent. ${ }^{3}$

The DTA curves of the coal waste (Fig.-1) are characterized by three endothermic effects at $470^{\circ} \mathrm{C}, 730^{\circ} \mathrm{C}$ and $775^{\circ} \mathrm{C}$. The first effect at $470^{\circ} \mathrm{C}$ characterizes the removal of crystalline hydrate moisture. Two other endothermic effects are characteristic for the decomposition of iron, calcium and magnesium carbonates. The endothermic effects at $780^{\circ} \mathrm{C}, 810^{\circ} \mathrm{C}$ and $830^{\circ} \mathrm{C}$ characterize the burning of iron sulphureous compounds and sulphates of impurity metals.

The infrared spectrum of the coal waste, represented in Fig.-2, show that:

- Less intensive absorption spectra at $1585.5 \mathrm{~cm}^{-1}$ are characteristic for sodium-containing carboxyl groups $-\mathrm{C}-\mathrm{ONa}$.

- Absorption spectra with wavelengths of 1090-1020 $(1033,8) \mathrm{cm}^{-1}$ show the presence of silicates with valency bonds $\mathrm{Si}-\mathrm{O}-\mathrm{Si}$ and $\mathrm{Si}-\mathrm{O}-\mathrm{C}$; also, they are characteristic for oxygen-containing ether groups. 
RASĀYAN J. Chem.

Vol. 13 | No. 3 |1372-1378| July - September | 2020

- Intensive fluctuations in the range of $910,4 \mathrm{~cm}^{-1}$ are typical of phosphorus-containing compounds and the benzene group $\mathrm{C}-\mathrm{O}-\mathrm{C}$.

- Absorption spectra in the interval of 794,6-752,2 characterize organic thiophene groups.

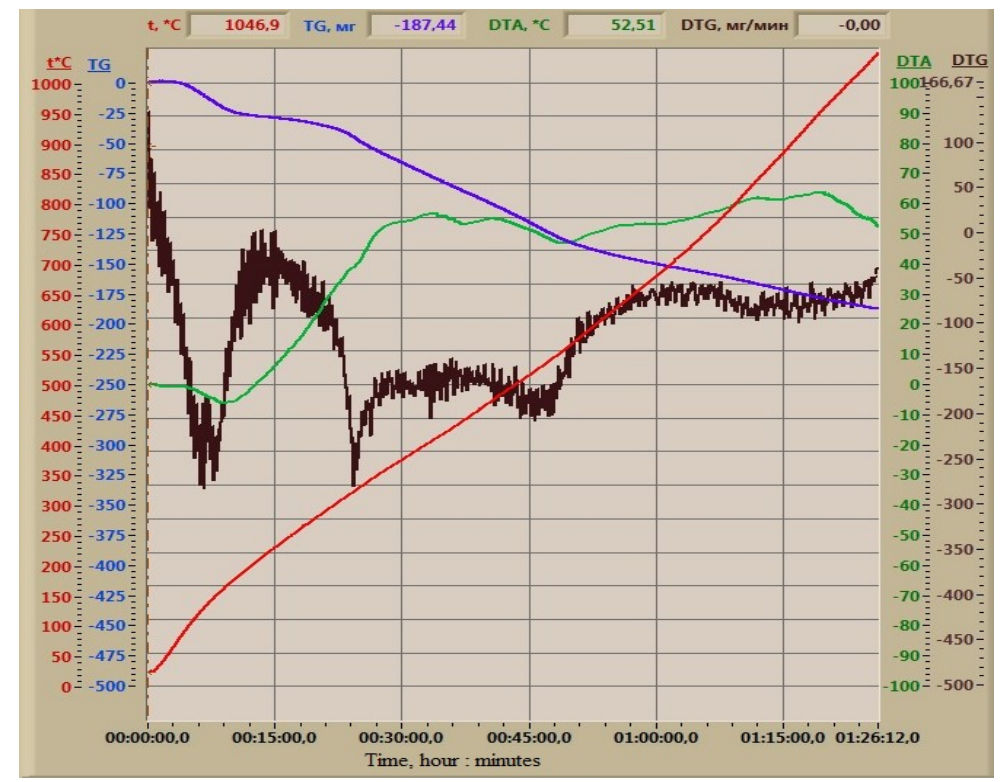

Fig.-1: The DTA Curves of the Coal Waste of the Lenger Deposit

The infrared spectral analysis of the coal waste was carried out using an IR-Fourier spectrometer Shimadzu IR Prestige-21 with a frustrated total internal reflection device Miracle (Pike Technologies).

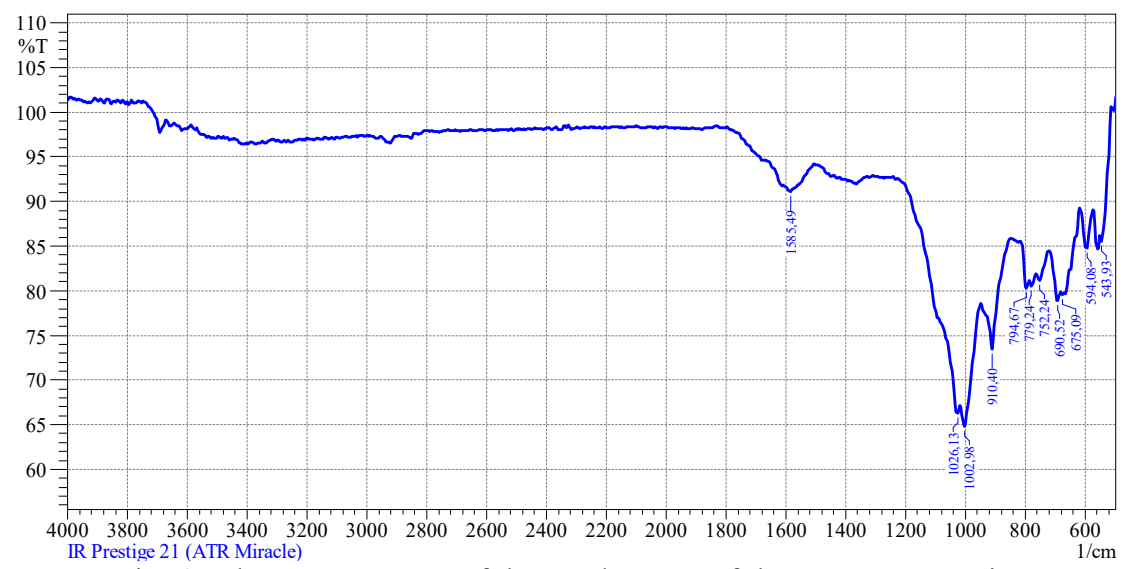

Fig.-2: The IR-Spectrum of the Coal Waste of the Lenger Deposit

The micrograph of the coal waste (Fig.-3) is characterized by the indistinct dense congestions of irregularshape crystals. The irregular hexahedral single minerals are evidence of the presence of calcium aluminates. The dark aggregates around the fine-crystalline aluminate minerals are characteristic of calcium and silicon ferrites. The sample contains quartz minerals (it is confirmed by fine chain aggregates) and also silicon aluminates and iron-containing minerals.

The analysis of the elemental composition shows that the sample of the Lenger deposit coal waste contains (\%): $\mathrm{Al}-3,92, \mathrm{Si}-8,06, \mathrm{Fe}-2,09, \mathrm{Mg}-0,30, \mathrm{Ti}-0,26$. Such elemental composition allows us to apply the waste as the initial raw material for obtaining humic acids.

With the view to increase the total extraction degree of humic components from the waste formed at the Lenger brown coal mining, and also to decrease losses of its valuable mineral constituents, the basic production process was finished at the stage of $\mathrm{HCl}$ acidifying of the alkaline extract formed at the 
RASĀYAN J. Chem.

Vol. 13 | No. 3 |1372-1378| July - September | 2020

leaching of the coal waste $(\mathrm{CW})$ with a potassium hydroxide solution. Then the insoluble residue of the coal waste - humine - was separated from the humine-acid suspension by centrifugation. The final target product represented the liquid colloid system with an average density of $0,98 \mathrm{~g} / \mathrm{cm}^{3}, \mathrm{pH}$ of 0,991 and the total humic acid concentration of $22-25 \%{ }^{4}$.
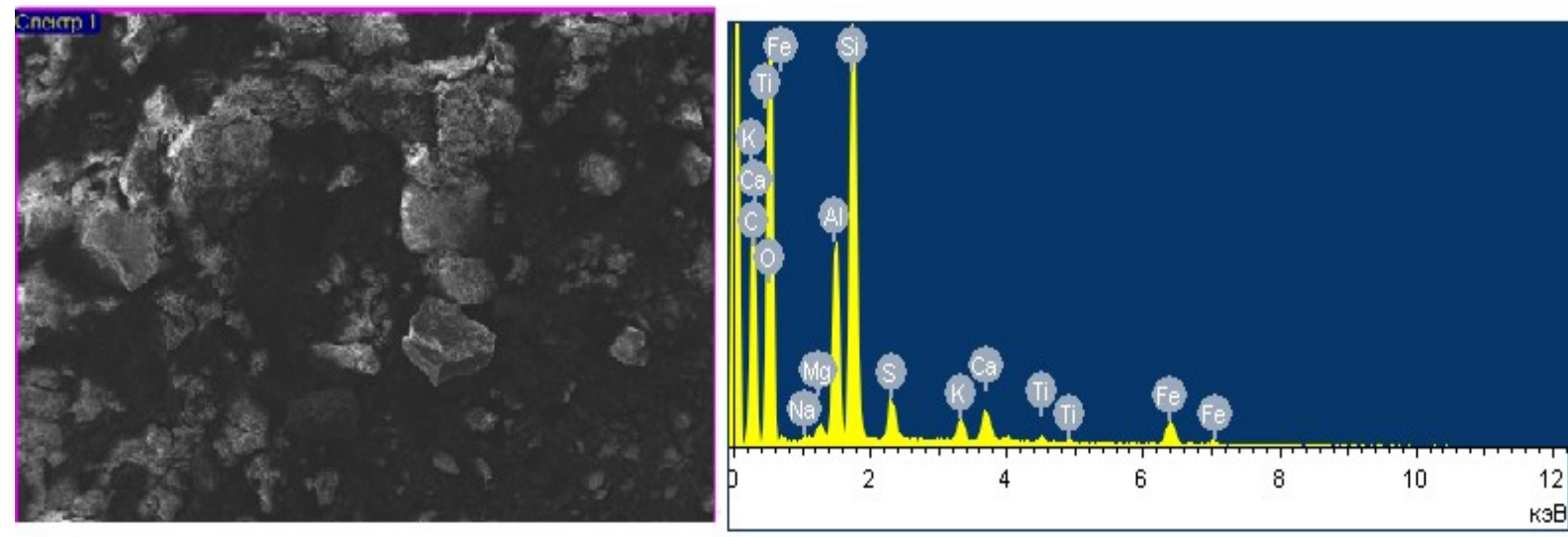

Fig.-3: The Micrograph of the Lenger Coal Waste

Table-2: Elemental and Mineralogical Composition of the Lenger Coal Waste

\begin{tabular}{c|c|c|c}
\hline Element & Mass $\%$ & Oxide & In term of Oxides, \% \\
\hline $\mathrm{C}$ & 42,96 & - & - \\
\hline $\mathrm{O}$ & 39,66 & - & 0,19 \\
\hline $\mathrm{Na}$ & 0,14 & $\mathrm{Na}_{2} \mathrm{O}$ & 0,50 \\
\hline $\mathrm{Mg}$ & 0,30 & $\mathrm{MgO}$ & 7,40 \\
\hline $\mathrm{Al}$ & 3,92 & $\mathrm{Al}_{2} \mathrm{O}_{3}$ & 17,27 \\
\hline $\mathrm{Si}$ & 8,06 & $\mathrm{SiO}_{2}$ & 1,78 \\
\hline $\mathrm{S}$ & 0,89 & $\mathrm{SO}_{3}$ & 0,80 \\
\hline $\mathrm{K}$ & 0,67 & $\mathrm{~K}_{2} \mathrm{O}$ & 1,47 \\
\hline $\mathrm{Ca}$ & 1,05 & $\mathrm{CaO}$ & 0,43 \\
\hline $\mathrm{Ti}$ & 0,26 & $\mathrm{TiO}_{2}$ & 2,98 \\
\hline $\mathrm{Fe}$ & 2,09 & $\mathrm{Fe}_{2} \mathrm{O}_{3}$ &
\end{tabular}

Chemistry of this process can be described in the following way:

$$
\begin{aligned}
& \mathrm{CW}+\mathrm{KOH} \rightarrow \mathrm{HA}-\mathrm{COOK}, \\
& \mathrm{HA}-\mathrm{COOK}+\mathrm{HCl} \rightarrow \mathrm{HA}-\mathrm{COOH}+\mathrm{KCl}
\end{aligned}
$$

Where, $\mathrm{HA}$ - $\mathrm{COOK}$ - potassium humate; $\mathrm{HA}$ - $\mathrm{COOH}$ - humic acid.

The extracted humic acid contains both organic compounds and mineral substances. To determine the inorganic components, the obtained humic acid was calcined at $500^{\circ} \mathrm{C}$. The elemental composition of the ash residue formed rest was determined on a scanning electronic microscope ISM-6490-LV (JEOL, Japan). The results are represented in Table-2.

The analysis of the data of Table- 3 shows the presence of sulphur that is obligatory for all humic acids. The absence of phosphorus, which content usually reaches $0,5 \%$, can be explained by the fact that the initial raw material was the coal mining waste. ${ }^{5}$

Figure- 4 shows the presence of the following infrared absorption spectra:

- Wide bands of intensive vibrations in intervals of 3400-3200 $\mathrm{cm}^{-1}\left(3360-3251,8 \mathrm{~cm}^{-1}\right)$, which are characteristic of the carboxylic acids with a bound - $\mathrm{OH}$ group and methyl, methylene groups;

- Intensive bands in the range of $1643,3 \mathrm{~cm}^{-1}$ which are characteristic for organic compounds of a carbonyl group of the aromatic series $\mathrm{C}(\mathrm{OH})=\mathrm{C}-\mathrm{CHO}$; 
RASĀYAN J. Chem.

Vol. 13 | No. 3 |1372-1378| July - September | 2020

- Low-intensity vibrations in the range of $1200-1300(1257,5) \mathrm{cm}^{-1}$ which are characteristic for aromatic aldehydes and formation of an oxygen bridge $\mathrm{C}-\mathrm{O}-\mathrm{C}$;

- Intensive vibrations in the range of $682,80-590,08 \mathrm{~cm}^{-1}$ which are characteristic for organic thiophen groups.

Table-3: The Elemental and Mineralogical Composition of the Humic Acid

\begin{tabular}{c|l|c|c}
\hline Element & Mass \% & Oxide & In terms of Oxide, $\%$ \\
\hline $\mathrm{O}$ & 23,68 & - & - \\
\hline $\mathrm{C}$ & 21,96 & - & - \\
\hline $\mathrm{Na}$ & 1,06 & $\mathrm{Na}_{2} \mathrm{O}$ & 1,43 \\
\hline $\mathrm{Al}$ & 2,70 & $\mathrm{Al}_{2} \mathrm{O}_{3}$ & 5,08 \\
\hline $\mathrm{Si}$ & 1,28 & $\mathrm{SiO}_{2}$ & 2,74 \\
\hline $\mathrm{S}$ & 1,51 & $\mathrm{SO}_{3}$ & 3,02 \\
\hline $\mathrm{Cl}$ & 24,52 & - & - \\
\hline $\mathrm{K}$ & 23,01 & $\mathrm{~K}_{2} \mathrm{O}$ & 27,61 \\
\hline $\mathrm{Fe}$ & 0,28 & $\mathrm{Fe}_{2} \mathrm{O}_{3}$ & 0,40 \\
\hline
\end{tabular}

During the research, it was found that the concentration of the humic acid obtained from the coal waste makes $22-25 \%(\mathrm{pH}$ is $-0,984)$ and its density is $1,01 \mathrm{~g} / \mathrm{cm}^{3}$. Production of chelate fertilizers based on the humic acid and ammophos is carried out according to the following scheme: $25 \mathrm{ml}$ of the humic acid and $75 \mathrm{ml}$ of electroactivated water are fed into a temperature-controlled reactor, add $5 \mathrm{~g}$ of ammophos, then the mixture is agitated at the temperature of $70^{\circ} \mathrm{C}$ within 60 minutes. ${ }^{6}$

The application of the numic acid for the ammophos decomposition allows us to avoid the use of sulfuric acid and to reach the assimilable phosphate content in the ready liquid product to $31 \%{ }^{7}$ The content of assimilable $\mathrm{P}_{2} \mathrm{O}_{5}$ depending on the ammophos decomposition in the hymic acid is represented in Table- 4 .

Table-4: Content of Assimilable $\mathrm{P}_{2} \mathrm{O}_{5}$ depending on the Ammophos Decomposition in the Hymic Acid

\begin{tabular}{c|c|c|c|c}
\hline Experiment & $\begin{array}{c}\text { Ammophos, } \\
\mathrm{g}\end{array}$ & $\begin{array}{c}\text { Humic Acid, } \\
\mathrm{ml}\end{array}$ & $\begin{array}{c}\text { Water, } \\
\mathrm{ml}\end{array}$ & $\mathrm{P}_{2} \mathrm{O}_{5}$ (Assimilable), \% \\
\hline 1 & 5 & 5 & 95 & 10,2 \\
\hline 2 & 5 & 10 & 90 & 19,4 \\
\hline 3 & 5 & 15 & 85 & 23,8 \\
\hline 4 & 5 & 20 & 80 & 27,4 \\
\hline 5 & 5 & 25 & 75 & 30,7 \\
\hline
\end{tabular}

In terms of the data of Table- 4 , the high content of assimilable phosphates in the ready liquid product $\left(5^{\text {th }}\right.$ experiment) reaches to $31 \%$. Such the phosphate content is enough for its use as a phosphorus-containing component for the manufacture of a polymer-containing micro fertilizer. Based on the data of Table-4 the $\mathrm{P}_{2} \mathrm{O}_{5}$ content-humic acid volume diagram was constructed.

Judging by Fig.-5, at the temperature of $70^{\circ} \mathrm{C}$ within 60 minutes with an increase in the humic acid volume the ammophos decomposition degree is $31 \%$.

Then the solution obtained was mixed with the additives: $0,5 \%$ of boric acid- $1 \mathrm{~g}, 0.5 \%$ of copper sulphate- $2 \mathrm{~g}, 1.5 \%$ of potassium sulphate- $2 \mathrm{~g}, 1.5 \%$ of ammonium molybdate- $2 \mathrm{~g}$ and $0.5 \%$ of EDPAN$2 \mathrm{ml}$. The mixture was agitated at a temperature of $70^{\circ} \mathrm{C}$ within 60 minutes. The end product represents the liquid chelate fertilizer with $\mathrm{pH}$ of 7.5.

\section{RESULTS AND DISCUSSION}

The mechanism of formation of chelate polymer-containing micro fertilizers was experimentally established using the element analysis technique and electronic microscopy. It was found that the presence of chelate polymer-containing micro fertilizers promotes the formation of an ammophos structure with individual sites of a crystalline structure. ${ }^{8}$

The analysis of the data obtained shows that the suggested polymer-containing micro fertilizer containing potassium humates and $\mathrm{Fe}, \mathrm{Mn}, \mathrm{Si}, \mathrm{Mg}, \mathrm{K}, \mathrm{Ca}, \mathrm{Al}, \mathrm{P}$ additives in the chelate form has an excellent 
RASĀYAN J. Chem.

Vol. 13 | No. 3 |1372-1378| July - September | 2020

operating ability and can be recommended for application at the cultivation of crops. The elemental composition of the micro fertilizer is represented in Table-5.

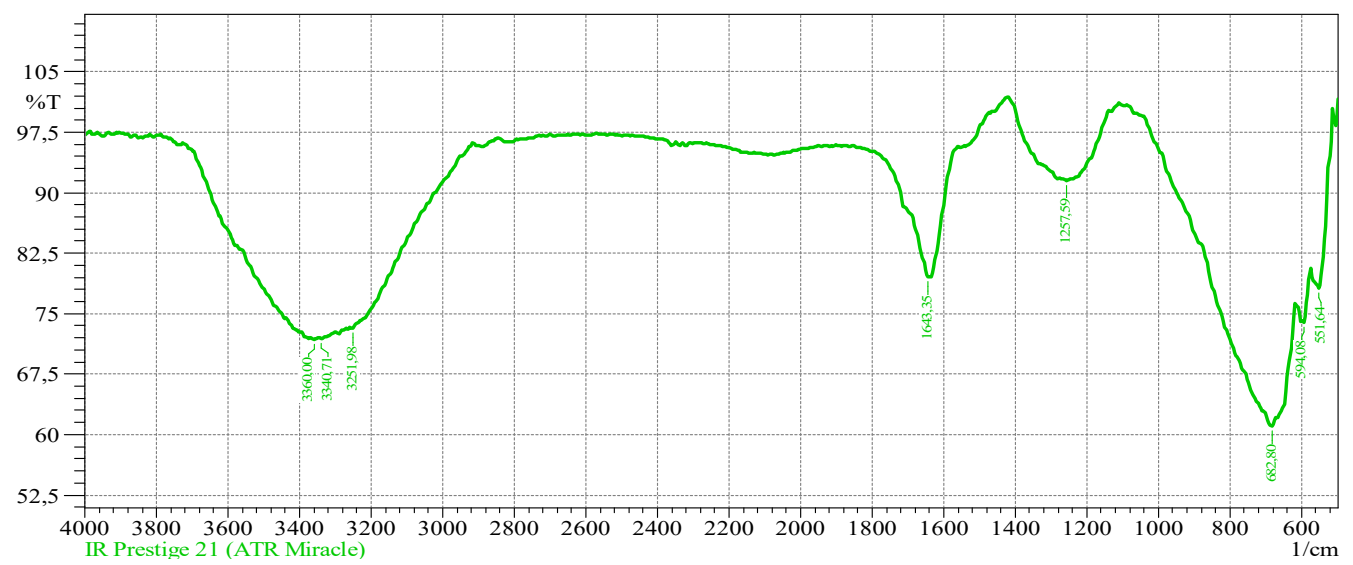

Fig.-4:The IR-Spectrum of the Humic Acid

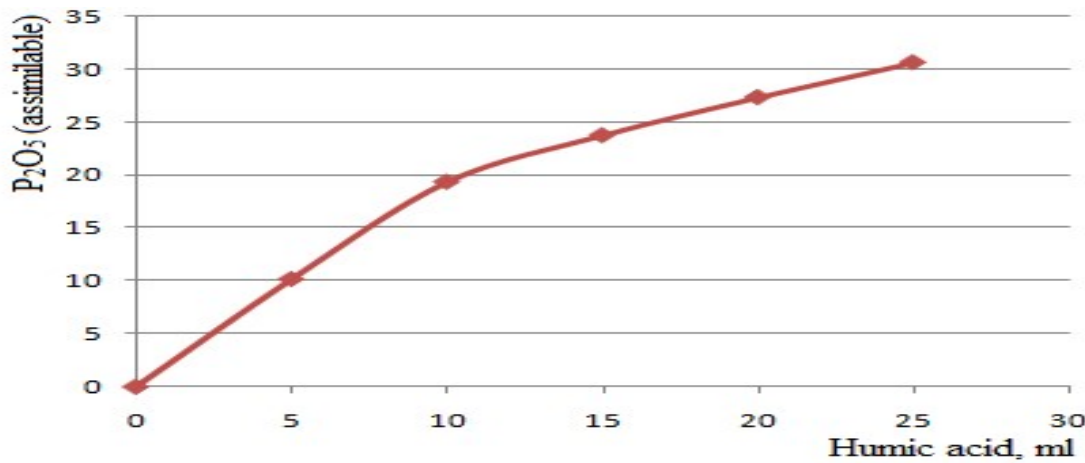

Fig.-5: Decomposition of Ammophos with the Humic Acid

Table-5: Elemental Composition of the Polymer-containing Micro Fertilizer

\begin{tabular}{c|c|c|c}
\hline Element & Mass $\%$ & Oxide & Oxide content, $\%$ \\
\hline $\mathrm{C}$ & 28,75 & - & - \\
\hline $\mathrm{O}$ & 32,64 & - & - \\
\hline $\mathrm{F}$ & 1,89 & - & 1,66 \\
\hline $\mathrm{Na}$ & 1,23 & $\mathrm{Na}_{2} \mathrm{O}$ & 1,22 \\
\hline $\mathrm{Mg}$ & 0,74 & $\mathrm{MgO}$ & 1,44 \\
\hline $\mathrm{Al}$ & 0,76 & $\mathrm{Al}_{2} \mathrm{O}_{3}$ & 7,66 \\
\hline $\mathrm{Si}$ & 3,58 & $\mathrm{SiO}_{2}$ & 30,56 \\
\hline $\mathrm{P}$ & 16,34 & $\mathrm{P}_{2} \mathrm{O}_{5}$ & - \\
\hline $\mathrm{S}$ & 0,22 & $\mathrm{SO}_{3}$ & 10,42 \\
\hline $\mathrm{Cl}$ & 8,65 & - & 4,76 \\
\hline $\mathrm{K}$ & 3,40 & $\mathrm{~K}_{2} \mathrm{O}$ & 0,14 \\
\hline $\mathrm{Ca}$ & 0,11 & $\mathrm{CaO}$ & 0,60 \\
\hline $\mathrm{Mn}$ & 0,42 & $\mathrm{MnO}$ & 0,35 \\
\hline $\mathrm{Fe}$ & 0,28 & $\mathrm{Fe} \mathrm{O}_{3}$ & \\
\hline
\end{tabular}

The polymer-containing micro fertilizer produced contains the microelements and minerals necessary for normal growth and development of plants $\left(\mathrm{K}_{2} \mathrm{O}-4,1 \%, \mathrm{P}_{2} \mathrm{O}_{5}-37,42 \%\right)$. The elemental composition and microstructure of the fertilizer sample are represented in Fig.-6.

The microscopic analysis of the finished product (Fig.-6) shows the presence of useful components and the presence of etherified derivatives of hydrolyzed polyacrylonitrile (EDPAN) promotes the formation of a grain crystalline structure of the chelate micro fertilizers. 
RASĀYAN J. Chem.

Vol. 13 | No. 3 |1372-1378| July - September | 2020

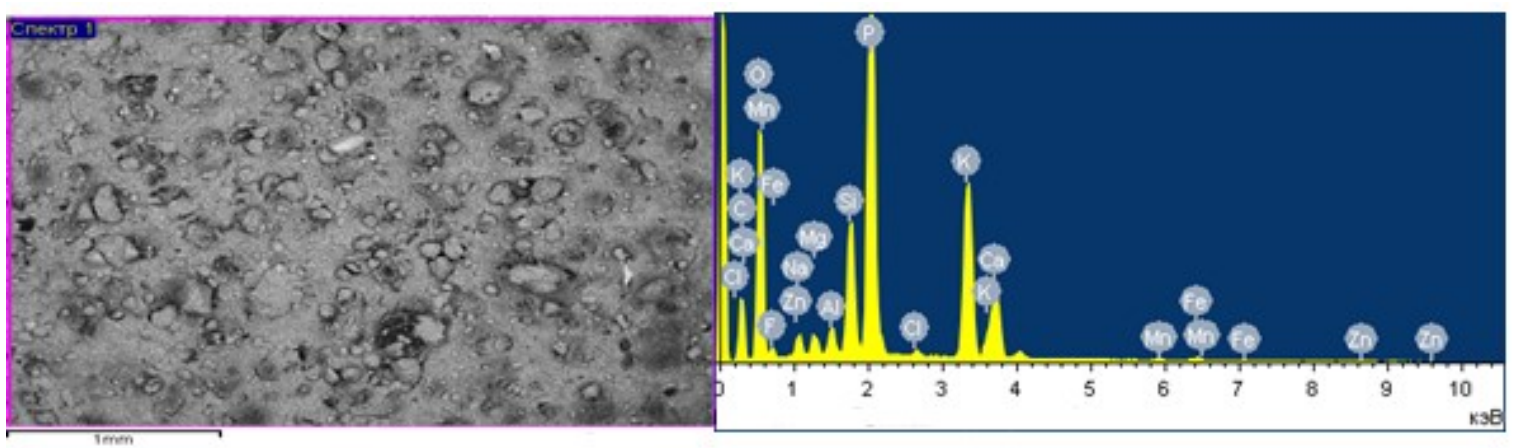

Fig.-6: The Micrograph of the Polymer-containing Fertilizer

\section{CONCLUSION}

The research showed that the etherified derivatives of hydrolyzed polyacrylonitrile (EDPAN) act as a chelation and transportation agent owing to the content of ether and carboxyl groups; it improves assimilability and inflow of microelements to plants.

It was established, that the micro fertilizer obtained is characterized by a high content of humic substances, which participate in soil structurization, accumulation of nutritious elements and microelements in the assimilable form, promote regulation of geochemical streams of metals in water and soil ecosystems. The mechanism of formation of chelate polymer-containing micro fertilizers was studied using the elemental analysis technique and electronic microscopy. It was established, that the presence of chelate polymer-containing micro fertilizers favors the formation of an ammophos structure and individual sites of a crystalline structure.

It was found, that application of such the fertilizers improves the soil structure, its buffer and ionexchange properties increases the activity of soil microorganisms. It is especially important to note the ability of plants to resist illnesses, drought, rehumidifying; at the applying the micro fertilizers of this type the level of crop yield increases that was proved by the results of field tests.

Based on the above-stated it is possible to conclude that the polymer-containing micro fertilizer actively participates in the biochemical processes, i.e. activates enzymes, shows the photosynthetic activity, takes part in chlorophyll biosynthesis, influences on the carbohydrate and nitrogenous metabolism, raises resistance to illnesses, and accelerates growth and development of plants.

\section{REFERENCES}

1. V.I. Butakov, B.V. Levinski, RF Patent № 2181113, 6C 05 F11/02. (2004).

2. http://newchemistry.ru, Accessed on 08.10.2019.

3. O.K.Beisenbayev, A.B. Issa and E. Kovaleva, Oriental Journal of Chemistry, 31 (4), 2369(2015), DOI: $10.13005 /$ ojc/310466

4. U.B. Nazarbek, Development of Phosphorus Sludge Processing Technologies for Targeted Fertilizer Products: Monograph: Department Chemical Technology of Inorganic Substances, M. Auezov South Kazakhstan State University, Shymkent, Kazakhstan, pp. 89-90, (2017).

5. O. K. Beisenbayev, A. S. Tleuov, B. M. Smaylov, B. S. Zakirov, International Scientific Association open European Academy of public sciences, "Fundamental and applied scientific research» International Scientific and Practical Conference. «Technology of obtaining chelate microfertilizer on the basis of technogenic wastes» March, 3, pp.45-51 (2019), Berlin, Germany.

6. V. P. Kovalchuk, V.G.Vasilyev, L.V. Boyko, V. D. Zosimov, Collection of Research Methods of Soils and Plants, pp. 252-256 (2010).

7. O.K. Beisenbayev, S.I. Umirzakov, A.S. Tleuov, B.M.Smaylov, A.B. Issa, Kh. Dzhamantikov, B.S. Zakirov, News of the National Academy of Sciences of the Republic of Kazakhstan, Series of Geology and Technical Sciences, 1(433), 80(2019), DOI: 10.32014/2019.2518-170X.10

8. V.M. Shevko, A.D.Badikova, D.D. Amanov , G.E. Karataeva, B.A. Lavrov, Rasayan J. Chem., 11 (3), 1050(2018), DOI: 10.31788/RJC.2018.1132038

[RJC-5726/2020] 